\title{
DIFFERENTIAL REGULATION OF SMOOTH MUSCLE CONTRACTION IN RABBIT INTERNAL ANAL SPHINCTER BY SUBSTANCE P AND BOMBESIN
}

\author{
Khalil N. Bitar, Craig Hillemeier, and Piero Biancani* \\ Division of Pediatric Gastroenterology, University of Michigan Medical Center, \\ Ann Arbor, MI 48109-0658. *Rhode Island Hospital, Brown University, Providence, RI. \\ (Received in final form october 22, 1990) \\ Summary \\ Substance $P$ and bombesin induce contraction of isolated IAS smooth muscle cells by \\ different intracellular mechanisms. The cells contracted in a dose dependent manner to \\ both peptides. The kinetics of contraction were different. Substance $P$ induced \\ contraction peaked at 30 seconds and declined in a time dependent manner while \\ bombesin induced contraction peaked at 30 seconds and was maintained for up to 8 \\ minutes. The absence of extracellular calcium in the medium ( 0 calcium and $2 \mathrm{mM}$ \\ EGTA) had no affect on substance $P$ induced contraction while it blocked bombesin \\ induced contraction. Substance $P$ induced contraction was blocked by the calmodulin \\ antagonist W7 (10-9 M) and was not affected by the PKC antagonist $\mathrm{H} 7\left(10^{-6} \mathrm{M}\right)$. \\ Bombesin induced contraction was blocked by the PKC antagonist $\mathrm{H} 7$ and was not \\ affected by the calmodulin antagonist $W 7$. Our data indicate that substance $P$ induces a \\ transient contraction utilizing intracellular calcium and a calmodulin dependent pathway, \\ while bombesin induces a sustained contraction utllizing calcium from extracellular \\ sources and a calmodulin independent pathway.
}

Substance $P$ and bombesin have been described within the neuronal cell bodies of the human intestinal tract and are present in the rectosigmoid region of the human gut (1). The cell bodies project caudad to other neurons and muscle cells within the curcular muscle layer $(2,3)$. Substance $\mathrm{P}$ and bombesin have been shown to have direct myogenic action in a variety of tissues (4-8).

There is evidence that binding of a contractile agonist to receptor sites on smooth muscle cells can follow the general pattern of stimulus-response coupling model for the phosphornositide cascade. Receptor activation of phospholipase $\mathrm{C}$ induces the hydrolysis of phosphatidylinositol 4,5-biphosphate (PIP2) to form the intracellular messengers Ins $(1,4,5)-\mathrm{P} 3$ and 1,2-DAG. Ins $(1,4,5)-\mathrm{P} 3\left(\mathrm{IP}_{3}\right)$ causes release of $\mathrm{Ca}^{++}$sequestered within intracellular stores and thereby elevates $\left[\mathrm{Ca}^{++}\right] \mathrm{i}$. We have previously shown that $\mathrm{CCK}$ contracts human gastric smooth muscle cells through the utilization of intracellular $\mathrm{Ca}^{+}+$release and that $\mathrm{IP}_{3}$ mimics this contraction (9). Agonist induced contraction in smooth muscle has been shown to elevate $\mathrm{IP}_{3}(10)$. We have shown that exogenously added $\mathrm{IP}_{3}$ induces contraction of IAS cells (11).

The other metabolite of PIP2 hydrolysis, 1,2 diacylglycerol (1,2 DAG), activates protein kınase C (PKC) which has the ability to phosphorylate regulatory proteins and bring about a response that may be independent of the $\mathrm{IP}_{3}$-calmodulin pathway. PDB (a phorbol ester), which presumably stimulates PKC, has been shown to cause tonic contractile activity in arterial smooth

Address Correspondence to:

Khalil N. Bitar, Ph.D.

University of Michigan Medical School

1510 E. MSRB I

Ann Arbor, MI 48109-0658 
muscle which is associated with a pattern of phosphorylated proteins different from what is seen when acute phasic contraction occurs in this muscle (12).

In the anorectal area the intracellular pathways mediating sustained and phasic contractule activity are not well defined. The aim of our study was to define the intracellular control mechanism responsible for mediating smooth muscle contraction in this region. Our data indicate that substance $\mathrm{P}$ induced- transient contraction utilizes intracellular calcium stores and is mediated by a calmodulin dependent pathway, whereas bombesin-induced sustained contraction utilizes calcium from extracellular sources and is mediated via a calmodulin independent pathway.

\section{Methods}

The sphincteric region was 1dentified as previously described (13). After anesthesia, the pelvic bone is opened and a $5 \mathrm{~cm}$ segment containing the terminal portion of the colon and rectum, including the anal sphincter, is measured and dissected free. The segment is opened with a midine incision along its antenor aspect, quickly rinsed, and pinned on a wax block at its in vivo length. The tissue is kept immersed in oxygenated Kreb's solution on ice. The junction of the rectal mucosa with the skin lining the outer portion of the canal is marked by sutures running through the whole thickness of the tissue; the external anal sphincter and the mucosa are removed by sharp dissection under a microscope, with care being taken not to disturb the sutures. Removal of the mucosa exposes the circular muscle layer; the circular fiber bundles are clearly visible. The internal anal sphincter, consisting of the distal most $3 \mathrm{~mm}$ of the circular muscle layer, ending at the junction of skin and mucosa, is removed by sharp dissection and digested to yield isolated smooth muscle cells.

The cells are isolated as previously described (14). The tissue is incubated for two successive 60 -min periods at $31^{\circ} \mathrm{C}$ in $15 \mathrm{ml}$ of HEPES buffer containing $0.1 \%$ collagenase $(150 \mathrm{U} / \mathrm{mg}$, Worthington CLS Type II) and $0.01 \%$ soybean trypsin inhibitor. At the end of the second enzymatic incubation period, the medium is filtered out through $500-\mu \mathrm{m}$ Nitex. The partly digested tissue left on the filter is washed four times with $50 \mathrm{ml}$ of collagenase-free buffer solution The tussue is then transferred into $15 \mathrm{ml}$ of fresh buffer solution and incubated for $30 \mathrm{~min}$ to allow the cells to disperse spontaneously. Only the cells that dissociate spontaneously in enzyme-free solution are used for functional studies. Cells are counted in a hemocytometer and diluted as needed. Each LAS yields $2-4 \times 10^{6}$ cells.

Muscle cells are examined within 30 min of dispersion. Aliquots consistıng of $2.5 \times 10^{4}$ cells in $05 \mathrm{ml}$ or medium are added to $0.1 \mathrm{ml}$ of a solution containing the test agents. In kinetic experiments the reaction is interrupted at various intervals $(5 \mathrm{sec}$ to $8 \mathrm{~min}$ ) by the addition of $0.1 \mathrm{ml}$ of acrolein at a final concentration of $1 \%$. In experiments where dose-response characteristics are examined, the reaction is interrupted at the time of peak contractile response $(30 \mathrm{sec})$. Individual cell length is measured by computerized image micrometry. The average length of cells in the control state or after addition of test agents is obtained from 50 cells encountered randomly in successive microscopic fields. The contractile response is defined as the decrease in the average length of the 50 cells and is expressed as the absolute change or the percent change from control length. W7 and H7 were obtained from Selkagaku America Inc, St Petersburg FL, Collagenase (CLS Type II) was obtained from Worthington. All other materials were obtained from Sigma, St Louis MO.

\section{Results}

The response to Substance $P$ was concentration-dependent (Fig. 1).A threshold response was attained at $10^{-11} \mathrm{M}$, a half-maximal response was observed at $10^{-9} \mathrm{M}$, and a maximal response was seen at $10^{-7} \mathrm{M}$. Maximal response to Substance $P$ by IAS cells was not significantly different from the maximal response to Ach $(35.7 \pm 1.2 \%$ versus $35.6 \pm 2.1 \%$ decrease in cell length from control). The same pattern of response was observed when IAS cells were stimulated with bombesin. The response was dose-dependent (Fig. 1) with a threshold dose for contraction at $10^{-11} \mathrm{M}$, a half-maximal response observed at $10^{-8} \mathrm{M}$ and a maximal response at $10^{-6} \mathrm{M}$. The kinetics of contraction of IAS cells in response to Substance $P$ and bombesin are shown in Fig. 2 
Substance P-induced contraction peaked at $30 \mathrm{sec}$ and then declined, while bombesin-induced contraction peaked at 30 seconds and was sustained for up to 8 minutes.

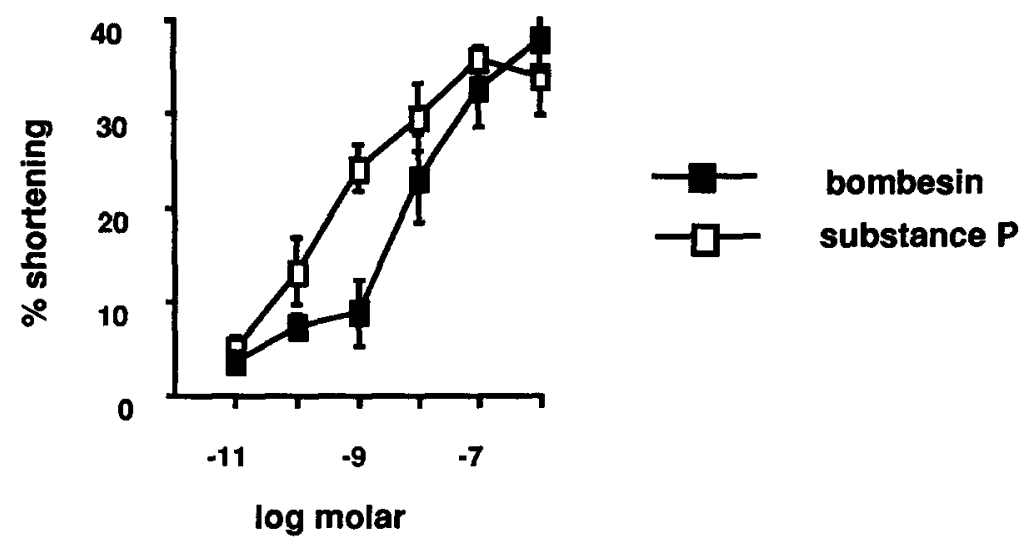

Figure 1

The response of smooth muscle cells from the IAS to bombesin and substance P. LAS cells were incubated with the indicated concentration of either bombesin or substance $P$ for 30 seconds. The data are shown as mean \pm SEM of 3 experiments for both bombesin and substance $P$.

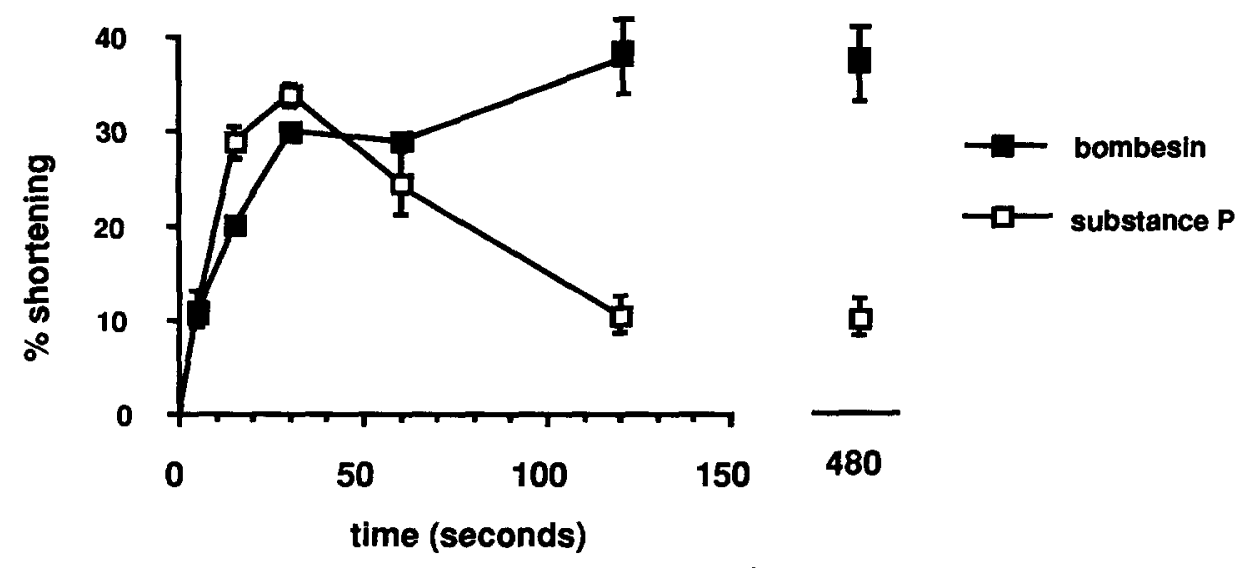

Figure 2

IAS cells were incubated with $\left(10^{-6} \mathrm{M}\right)$ substance $P$ and bombesin for the indicated time. Substance $P$ induced contraction peaks at 30 seconds and decreases in a time dependent manner. Bombesin induced contraction peaks at 30 seconds and remains elevated up to 8 minutes later. Data are expressed as mean \pm SEM of 3 experiments

Preincubation of these cells for 60 seconds with the calmodulin antagonist W7 (10-9M) blocked maxımal substance P-induced contraction, but had no effect on bombesin-induced contraction (Fig. 3). Preincubation of the cells for 60 seconds with the PKC antagonist H7 (10-6M) blocked the bombesin-1nduced contraction and had no effect on the substance P-induced contraction (F1g. 3) 

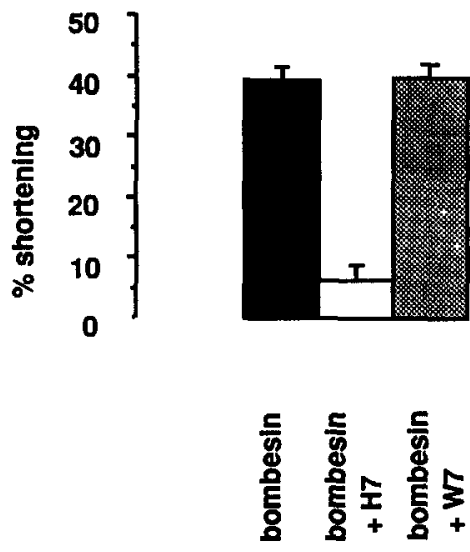

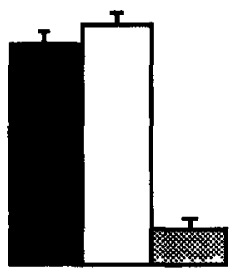

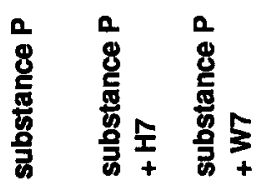

Figure 3

Bombesin $\left(10^{-6} \mathrm{M}\right)$ induced contraction of IAS isolated smooth muscle cells is blocked by the Protein Kinase $\mathrm{C}$ antagonist $\mathrm{H} 7\left(10^{-6} \mathrm{M}\right)$, but is not affected by the calmodulin antagonist W7 $\left(10^{-9} \mathrm{M}\right)$. Conversely, substance $\mathrm{P}\left(10^{-6} \mathrm{M}\right)$ induced contraction is blocked by W7 and not by H7. Data are expressed as mean \pm SEM of 3 experiments.

It has been established that changes in cytosolic calcium $\left[\mathrm{Ca}^{++}\right]_{1}$ are associated with changes in the contractile state of smooth muscle. The role of calcium in generating a brief "phasic" or a sustained "tonic" contraction is important. Our data from isolated cells of the rabbit IAS suggest that substance $P$ and bombesin preferentially utilize different sources of calcium to induce contraction. Substance $\mathbf{P}$ utilizes $\mathrm{Ca}^{++}$released from intracellular stores, as substance $\mathrm{P}$ induced contraction is not affected by incubation in Ca+-free medium ( $0 \mathrm{Ca}^{+} / 2 \mathrm{mM} \mathrm{EGTA}$ ) or by $\mathrm{Ca}^{++}$ channel blockers. Bombesin utilizes influx of extracellular $\mathrm{Ca}^{++}$as bombesin-induced contraction is blocked under the same circumstances (Fig. 4). These data suggest that agonist induced contraction 1n the same muscle may utilize discrete sources of $\mathrm{Ca}^{++}$and thus provide a further possible mechanism for differential kinetics of contraction.

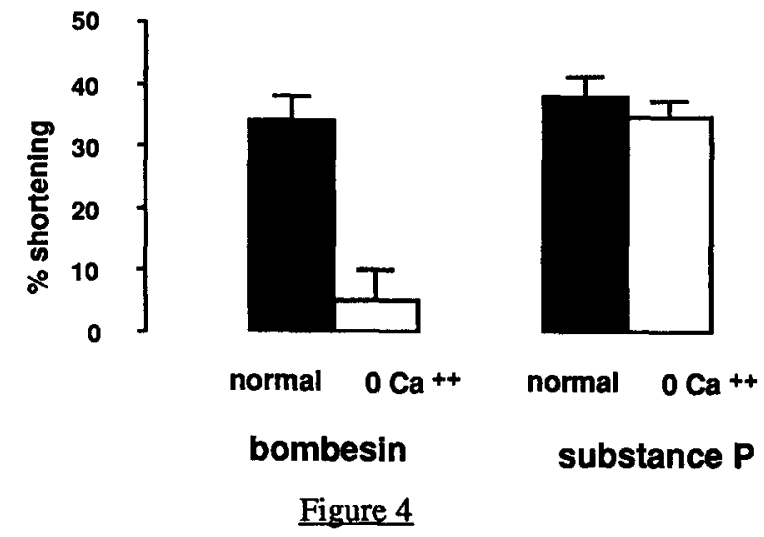

Response of isolated cells from IAS to $\left(10^{-6} \mathrm{M}\right)$ bombesin and substance $P$ in normal buffer and in the absence of extracellular $\mathrm{Ca}^{++}$with $2 \mathrm{mM}$ EGTA. Data are expressed as \pm the SEM of 3 experiments. 


\section{Discussion}

Substance $\mathrm{P}$ and bombesin have been described to be contained within the neuronal cell bodies of the human intestinal tract, do not have projections into the epithelial cells (15) and are present in the rectosigmoid (1). They have been shown to have direct myogenuc action in a variety of tissues (4-8). The purpose of this investigation is to determine the effect and mode of action of these two peptides in the anal sphincter, and to examine their interaction in producing contraction and maintenance of tone.

The IAS is characterized by the ability to maintain tone, and to relax allowing the passage of feces. IAS tone is thought to be spontaneous and regulated predominantly through myogenic mechanisms (16-19). IP3 mediated release of intracellular $\mathrm{Ca}^{++}$leads to activation of $\mathrm{Ca}^{++}$ sensitive proteins, such as a calmodulin-dependent protein kinase, which causes contraction via the phosphorylation of specific sites on the 20,000 dalton myosin light chain (20-25) The other PtdIns $(4,5) \mathrm{P}_{2}$ metabolite, 1,2 diacylglycerol, can activate Protein Kinase C (PKC) which has the ability to phosphorylate regulatory proteins and bring about responses that may be independent of the $\operatorname{Ins}(1,4,5) \mathrm{P}_{3} /$ calmodulin pathway.

In IAS cells the addition of either exogenous Ins $(1,4,5) \mathrm{P}_{3}$ or PKC causes shortening in a dose-dependent manner (11) that is similar in efficacy, but is selectively inhibited by W7 in the case of Ins $(1,4,5) \mathrm{P}_{3}$ and by $\mathrm{H} 7$ in the case of PKC. The tume course of IAS cell contraction that is seen with Ins $(1,4,5) \mathrm{P}_{3}$ shows a peak response at 5 seconds and then decreases in a time dependent manner. PKC-induced contraction is slower in developing, peaking at thirty seconds and remains elevated for up to eight minutes. The different kinetics and sensitivity to antagonists suggests that IP3 and PKC mediated contraction follow distinct intracellular pathways.

Our data indicate that substance P-induced contraction of the internal anal sphincter similar to exogenous IP3, may be mediated by intracellular $\mathrm{Ca}^{++}$release through a calmodulin dependent pathway, while bombesin-induced contraction is dependent on $\mathrm{Ca}++$ from extracellular sources and a PKC mediated, calmodulin-independent pathway (Fig. 3). The kinetics of contraction induced by bombesin and exogenously added PKC are similar but differ from contraction induced by substance $\mathrm{P}$ or exogenously added $\mathrm{IP}_{3}$. The contractions in response to substance $\mathrm{P}$ and $\mathrm{IP}_{3}$ are transient, peaking rapidly and then declining, while the contractions induced by bombesin and PKC develop more slowly and persist for a prolonged period. The sustained contraction observed in isolated cells may reflect tonic contraction in vivo. It is possible that tone may not be totally dependent upon $\mathrm{Ca}^{+}$release from intracellular stores and is dependent on PKC in a manner similar to what is seen in the tonic contraction observed with PKC activators (26-30).

The existence of distunct mechanisms in the same cell implies that depending on the receptors activated by different agonists, different proportions of IP3 or DAG may be produced. The data are consistent with the hypothesis that bombesin may activate almost exclusively phospholipases responsible for formation of DAG, possibly by hydrolysing phosphatidylcholine (PC), without production of IP3 (31-33).

\section{Acknowledgements}

This work was supported by a grant from the Department of Pediatrics at the University of Michigan Medical School. We would like to thank Diane Ar and Stephane Stein for their technical assistance and Colleen Croxall for her help in preparing this manuscript.

\section{References}

1. G. FERRI, T. ADRIAN, J. ALLEN, L. SOIMERO, A. CANCELLIERI, J. YEATS, M. BLANK, J. POLAK, and S. BLOOM. Gut. 29: 762-768 (1988). 
2. M. COSTA J.B. FURNESS, N. YANAIHARA, C. YANAIHARA, and T.W. MOODY. Cell Tissue Res. 235: 285-293 (1984).

3 E. EKBLAD, R. EKMAN, R. HAKANSON, and F. SUNDLER. Regul. Pept. 9: 279-287 (1984).

4. R. MICHELETTI, J.R. GRIDER, and G.M. MAKHLOUF. Reg. Peptides 21: 219-226 (1988).

5. J.C. REYNOLDS, M.R. DUKEHART, A. OUYANG, and S. COHEN. J. Clin. Invest. Feb; 77: 436-440 (1986).

6. C. SEVERI, J.R. GRIDER, and G.M. MAKHLOUF. J. Pharm. Exp. Ther. 245: 195-98 (1988).

7. J. SOUQUET, K. BITAR, J. GRIDER, and G. MAKHLOUF. Am. J. Physiol. 193: G666-G672 (1987).

8. J. SOUQUET, J. GRIDER, K. BITAR, and G. MAKHLOUF. Am. J. Physiol 193: G533-G538 (1985).

9. K. N. BITAR, P. BRADFORD, J.W. PUTNEY, JR., and G.M. MAKHLOUF. Science. 232: 1143-1145 (1986).

10. Y. NISHIZUKA. Science 225: 1365-1370 (1984).

11. K.N. BITAR, C. HILLEMEIER, P. BIANCANI, and K.J. BALAZOVICH Am J. Physiol. (in press 1990).

12. Y. TAKUWA, G. KELLY, N. TAKUWA, and H. RASMUSSEN. Mol. Cell. Endocrin 60: 71-86 (1988).

13. P. BIANCANI, J. WALSH and J. BEHAR. Gastroenterology 89: 867-874 (1985).

14. K.N. BITAR and G.M. MAKHLOUF. Am. J. Physiol. 242: G400-407 (1982).

15. G.L. FERRI, T.E. ADRIAN, M.A. GHATEI, D.J. O'SHAUGHNESSY, L. PROBERT, Y C. LEE, A.M. BUCHAN, J.M. POLAK, and S.R. BLOOM. Gastroenterology 84: 777786 (1983).

16. P. BIANCANI, C. HILLEMEIER, K. BITAR, and G MAKHLOUF. Am J. Physiol. 193: G760-G766, 1987.

17. K.N. BITAR, P. BRADFORD, J. PUTNEY, and G. MAKHLOUF. J. Biol. Chem. 261(35): 16591-16596 (1986).

18 S. HOLMGREN, J. JENSEN, A.C. JONSSON, K. LUNDIN, and S. NILSSON. Cell Tissue Res. 241: 565-580 (1985).

19. A. KRAFT and W. ANDERSON. Nature. 301: 621, 1983.

20. K.N. BITAR, G. BURGESS, J. PUTNEY, and G. MAKHLOUF. Am. J Physiol. 193: G280-G286 (1986).

21 F.S FAY and K FOGARTY. in: Smooth Muscle Contraction (Stephens, J.L., ed) pp. 7590, Marcel Dekker Inc., New York (1984).

22 E. LAZARIDES. Annu. Rev. Biochem. 51: 219-250 (1982).

23. K. LEE, S.H. RYU, P. SUH, W.C. CHOI, and S.G. RHEE. Proc. Nat. Acad Sc1. (USA). 84: 5540 (1987).

24. T.S. LEE, T. CHAO, K.Q. HU, and G.L. KING. Biochem. Biophys. Res. Com. 162:381-386 (1989).

25 K.N. BITAR and G. MAKHLOUF. Am. J. Physiol. 193: G357-G360 (1986)

26. K.N. BITAR and G. MAKHLOUF. Science. 216: 531-533 (1982).

27. C. BRONNER, C. WIGGINS, D. MONTE, F. MARKI, A. CAPRON, Y. LANDRY, and R.C. FRANSON. Biochim. Biophys. Acta. 920: 301 (1987).

28. S.J. COOK and M.J.O. WAKELAM. Blochem. J. 263: 581-587 (1989).

29. N. HAILAT, J.R. STRAHLER, R.F. MELHEM, X. ZHU, B. RICHARDSON, D. FOX, and S. HANASH.Submitted.

30. D.J. HARTSHORNE and R.F. SIEMANKOWSKI. Annu. Rev. Biochem. 43: 519-530 (1981).

31. J.-H. EXTON. J. B1ol. Chem. 265: 4-1 (1990).

32. A.P. TRUETT, M.W. VERGHESE, S.B. DILLON, and R. SNYDERMAN. Proc. Natl. Acad. Sc1. U.S.A. 85: 1549-1553 (1988).

33. T. MATOZAKI AND J.A. WILLIAMS. J. Biol. Chem. 264: 14729-14734 (1989). 